\title{
Sociobiology
}

RESEARCH ARTICLE - BEES

\section{Spectrum of Pollen Stored by Melipona mandacaia (Smith, 1863) (Hymenoptera: Apidae, Meliponini) in an Urban Arid Landscape}

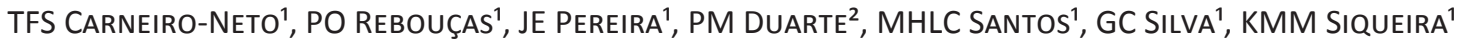 \\ 1 - State University of Bahia, DTCS, Juazeiro-BA, Brazil \\ 2 - Federal University of Ceará, Departament of Agronomy, Fortaleza-CE, Brazil
}

\section{Article History \\ Edited by \\ Evandro N. Silva, UEFS, Brazil \\ Received 28 November 2016 \\ Initial acceptance 24 May 2017 \\ Final acceptance 05 July 2017 \\ Publication date 17 october 2017}

\section{Keywords}

Stingless bee, Collection of pollen, Trophic niche, Caatinga.

\section{Corresponding author}

Thiago Francisco de Souza Carneiro Neto Departamento de Tecnologia e Ciências Sociais, Universidade do Estado da Bahia Rua Edgar Chastinet, s/n - São Geraldo CEP 48905-680, Juazeiro-BA, Brasil. E-Mail: thiagofs_10@hotmail.com

\begin{abstract}
The objective of this study was to identify the species of pollen supplying plants that constitute the trophic niche of Melipona mandacaia in an urban area in the Caatinga domain (a tropical arid landscape). The collection of pollen in the colonies was carried out every 15 days, from October 2014 to September 2015. The pollen was removed directly from the storage pots in three distinct colonies. A total of 24 samples were analyzed and compared with the reference pollen collection, pollen catalogs and specialized literature. For the quantitative analysis, at least 1000 pollen grains per sample were identified. A total of 39 pollen types were identified, distributed in 17 botanical families, being one an indeterminate type. The most represented family was the Fabaceae $(n=16)$. The most frequent types were Leucaena leucocephala, Mimosa pudica and Melochia sp. There was a significant positive correlation between temperature and the number of pollen types throughout the study. Relative humidity and rainfall were abiotic variables that did not present a significant correlation. The rarefaction curve showed that probably most of the pollen types collected by the bees studied were sampled, since the accumulation curve showed a progressive tendency to stabilization, indicating that there was sample adequacy of the pollen types. The analysis of similarity revealed a high sharing of pollen sources between colonies.
\end{abstract}

\section{Introduction}

The Melipona mandacaia (Smith, 1863), is one of the mostknown stingless bee in the semiarid regions in northeastern Brazil, thereby being an animal of permanent coexistence in the rural areas (Alves et al., 2006), distributed in the Caatinga (dry bushland) biome (Batalha-Filho, et al., 2011). This is a generalist bee, endemic, and little studied, possibly due to its region of occurrence (Prado-Silva et al., 2016; Nunes, 2008).

The bees of the Caatinga biome play an important role in the pollination of native and cultivated plants, which contributes to the formation of more robust and better quality fruits for the producer market (Siqueira et al., 2011). The flora of the Caatinga basically provides the food resources to the bee's population when the orchard plants are not flowery. However, knowledge of the bee fauna of this biome and the resources used are still very scarce, although rich in species and endemism.

However, natural ecosystems have been affected for many years by the destruction of the original vegetation in order to use them for agriculture or livestock (RamírezArriaga et al., 2011). The simplification of these landscapes due to the intensive use of the soil has led to changes in the pollinator community structure. Among the anthropogenic actions, the indiscriminate use of agrochemicals, fires and deforestation are considered the main threats to biodiversity (Steffan-Dewenter et al., 2006). The intense deforestation 
of the Caatinga has brought harmful consequences for $M$. mandacaia (Batalha-Filho et al., 2011).

Given their ecological importance as pollinators of many native plant species, knowledge of the sources of food used by stingless bees, as well as the spatio-temporal distribution of the resources that maintain their colonies, and the strategies adopted by them in the face of variations of environmental factors have great ecological and economic importance in this group of bees. (Aleixo et al., 2013; Imperatriz-Fonseca et al., 2012). This way, the complementation of ecological data, obtained through the palynological analyses, is an important step in the rational exploration for the development of the preservation programs for these bees. The planning of urban green spaces using native species is important from a conservation perspective, since it favors the maintenance of several kinds of interactions between plants and pollinators (Aleixo et al., 2014). This may help direct efforts to recover vegetation in affected areas using botanical species that guarantee food supply (Luz et al., 2011; Wiese, 1985).

In this context, the objective of this study was to identify the species of plants supplying pollen, to verify the existence of correlation between biotic variables (pollen types) and abiotic variables, and the sharing of the trophic niche of Melipona mandacaia in an urban area in the Caatinga vegetation domain (a tropical arid landscape).

\section{Material and methods}

The experiment was conducted in the meliponary of the Department of Technology and Social Sciences - DTCS of Campus III - UNEB in Juazeiro-Bahia $\left(09^{\circ} 25,43.6^{\prime \prime} \mathrm{S}\right.$, $40^{\circ} 32^{\prime} 14^{\prime \prime} \mathrm{W}, 384 \mathrm{~m}$ ) (Fig 1). The climate of the region according to the classification of Köppen is BSwh' hot dry, semi-arid with an annual average rainfall of $542 \mathrm{~mm}$, with rainfall concentrated in the period from October to April (EMBRAPA, 2015).

The pollen was collected every 15 days during the period from October 2014 to September 2015. The pollen was collected directly from the storage pots in three colonies of M. mandacaia. They were found open, indicating their recent use. A total of 24 samples were analysed. The macroclimatic data, such as rainfall, temperature and relative humidity, were obtained through the UNEB-Campus III Meteorological Station.

\section{Preparation of slides and identification of pollen types}

The samples were placed in eppendorf type microtubes and taken to the Entomology Laboratory. For each sample, three slides were prepared in Kisser's glycerin gelatin, following the method of Maurizio and Louveaux (1965), without acetolysis. In the same sampling period, flowering plants were photographed for subsequent identification, being collected in transects up to $500 \mathrm{~m}$ from the meliponary. Reference slides with pollen from anthers were made, using the same methodology already described.

The identification of the pollen types was carried out under a Zeiss Primo Star optical microscope with a 40x objective, comparing with the reference pollen collection, pollen catalogs and specialized literature. For the quantitative analysis, a minimum of 1000 pollen grains per sample was recorded.

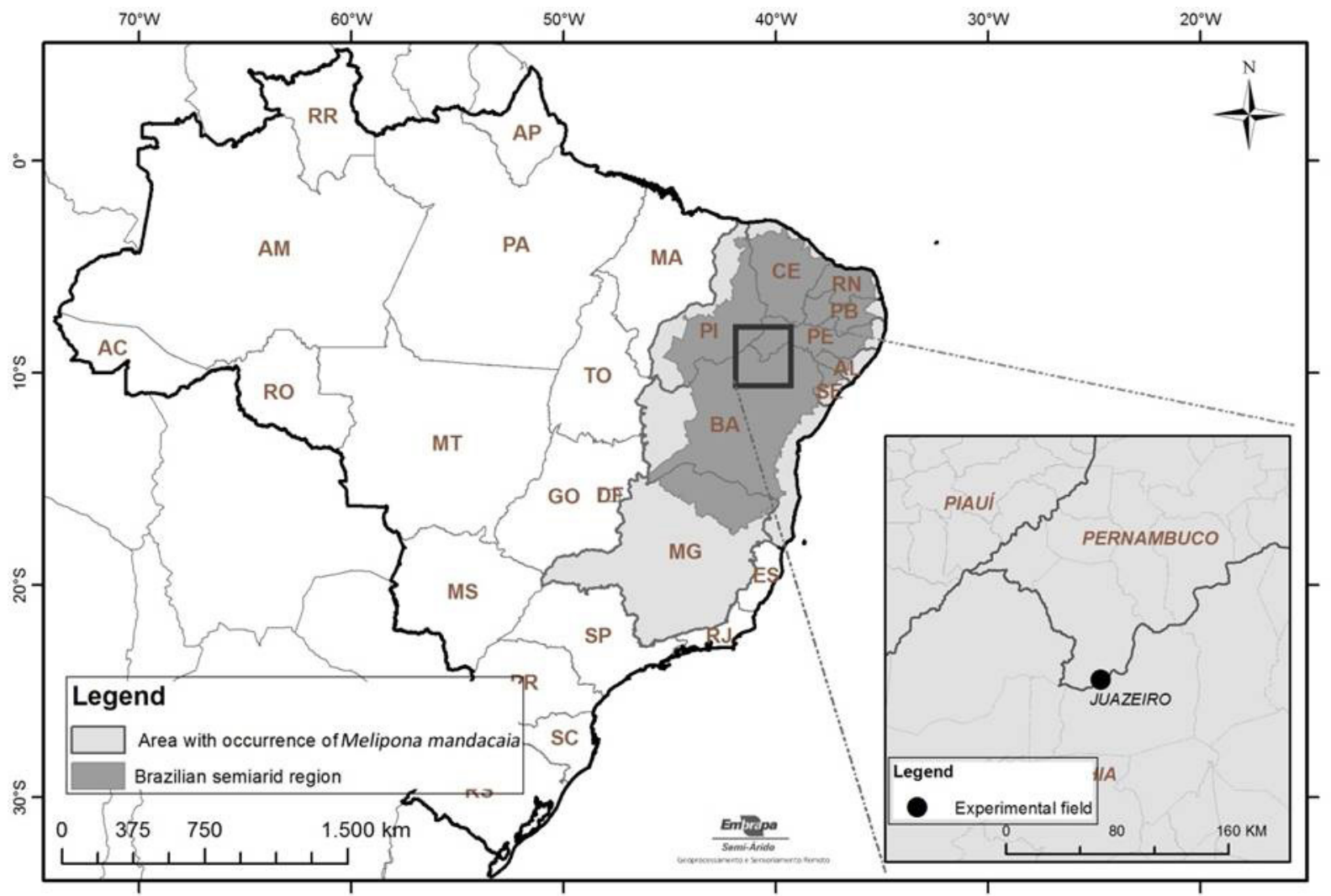

Fig 1. Geographical location of Melipona mandacaia occurrence and of the study area, Campus III-UNEB, Bahia, northeast Brazil. 
Statistical analysis

For the analysis of the pollen types the frequency was expressed in percentage and grouped in the following classes according to Novais et al. (2009): very constant (VC), present in $>75 \%$ of the samples; constant $(\mathrm{C}),>50 \%-\leq 75 \%$; Low constancy (LC), $>25 \%-\leq 50 \%$; occasional $(\mathrm{O}), \geq 5 \%-\leq 25 \%$; and rare $(\mathrm{R}),<5 \%$, considering only the simple presence or absence of a pollen type in any of the samples.

The trophic niche amplitude was calculated by the Shannon index ( $\left.\mathrm{H}^{\prime}\right)$, using the algorithm $\mathrm{H}^{\prime}=-\Sigma \mathrm{pk} \mathrm{x} \ln \mathrm{pk}$, where pk is the ratio of the number of grains counted by each pollen type $(\mathrm{k})$ and the total counted pollen. The uniformity of resource use was calculated by the Pielou index ( $\left.\mathrm{J}^{\prime}\right)$, using the formula J' = H '/ H'max (Ludwig \& Reynolds, 1988). For this the PAST software, version. 1.85 was used (Hammer et al., 2001).

The normality of the data was tested by the ShapiroWilk test (W), verifying that the data did not present normal distribution. For this reason, a simple regression analysis was applied through the Spearman correlation coefficient $(\rho)$ to verify the existence of correlation between biotic variables, pollen types and abiotic variables such as temperature, rainfall and relative humidity. Significant correlations were considered when $\mathrm{p}<0.05$, by the Student $\mathrm{t}$ test. The analyses were done using PAST software version 1.85 (Hammer et al., 2001).

The Collector Curve was constructed by accumulating the number of pollen types collected by the workers and stored in the pollen pots of their nests during the period of this study. To estimate the total richness of the pollen types that occurred in the study area, Colwell \& Coddington (1994) were used. In addition, the Chao 2, Jacknife 1 and Bootstrap wealth estimators, 100 times randomized by the Estimate $\mathrm{S}$ 9.1.0 program (Colwell, 2013), were used to determine the sample sufficiency of the bees' guild.

The similarity coefficient proposed by Sörensen (Cs) (Sörensen, 1948 apud Magurran, 2011) was used to evaluate the degree of similarity in the composition of the pollen types of the boxes of M. mandacaia, varying from 0 to 1 . Considering high similarity when values of $\mathrm{Cs}>0.7$. The coefficient of similarity of Sörensen was calculated using the formula $\mathrm{Cs}=2 \mathrm{a} / 2 \mathrm{a}+\mathrm{b}+\mathrm{c}$, where: $\mathrm{a}=$ number of common types occurring in the two colonies (box $\mathrm{A}$ and $\mathrm{B}$ ); $\mathrm{B}=$ number of types occurring in colony $\mathrm{A}$ and not in $\mathrm{B} ; \mathrm{C}=$ number of types that occurs in colony $\mathrm{B}$ and not in colony $\mathrm{A}$.

\section{Results}

A total of 39 pollen types were identified, distributed in 17 botanical families, being one an indeterminate type (Table 1). The most represented family was Fabaceae with 16 pollen types distributed in three subfamilies: Caesalpinioideae (n $=4)$, Mimosoideae $(\mathrm{n}=11)$ and Papilinioideae $(\mathrm{n}=1)$. The most frequent types were Leucaena leucocephala (35.82 \%), Mimosa pudica (15.66\%) and Melochia sp. (13.32\%). Most of the pollen types found during the study period belonged to the Mimosoideae (Fabaceae).

The largest pollen spectrum (21 pollen types) was found in sample I (Oct/2014), however the highest contribution of pollen grains was concentrated in the L. leucocephala type $(62.26 \%)$, which resulted in a reduced uniformity of the trophic resources $(\mathrm{J} '=0.5)$ stored in the pollen pots of $M$. mandacaia. The samples XVIII (Jun/2015), XIX (Jul/2015) and XXIII (Set/2014) presented the lowest spectrum, with six pollen types each.

The amplitude of the trophic niche, based on the pollen stored in the pots of the studied colonies, ranged from 0.64 to 2.27, given that sample XXIII (Set/2015) obtained the lowest diversity value (H') and sample VI (Dec/2014) presented the highest value. The uniformity of use of these resources in pollen samples ranged from 0.36 to 0.87 , given the lowest value found for sample XXIII for September/2015, and the highest value for sample IV, which was collected in November, 2014.

There was a significant positive correlation between temperature and the number of pollen types $(\rho=0.6455$; $\mathrm{P}=$ 0.0234 ) throughout the study (Fig 2 ). The relative humidity $(\rho=-0.2035, P=0.5258)$ and rainfall $(\rho=0.4205 ; P=$ 0.1735 ) were abiotic variables that did not present a significant correlation with the number of pollen types collected by bees.

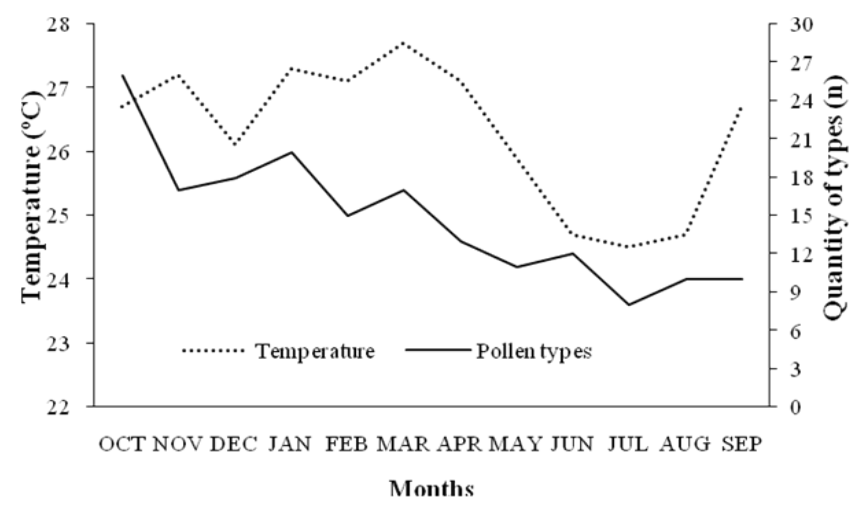

Fig 2. Relationship between the monthly average temperature and the number of pollen types during the period from October/2014 to September/2015in an urban arid landscape.

Comparing the analyses made with richness estimators the number of pollen types varied between 39 (Chao 2) and 46 (Jack 1) found along the 24 samples collected in the study period (Fig 3). However, the estimator curves did not stabilize, indicating that the increase in sample effort could increase the number of estimated types.

For the similarity analysis, a qualitative metric was used (Sorensen Index), which revealed a high share of the pollen sources among the colonies of $M$. mandacaia studied since the value of this index was high $(\mathrm{Cs}>0.7)$. The colony I + colony II group presented the highest similarity among the three boxes studied (Table 2). 


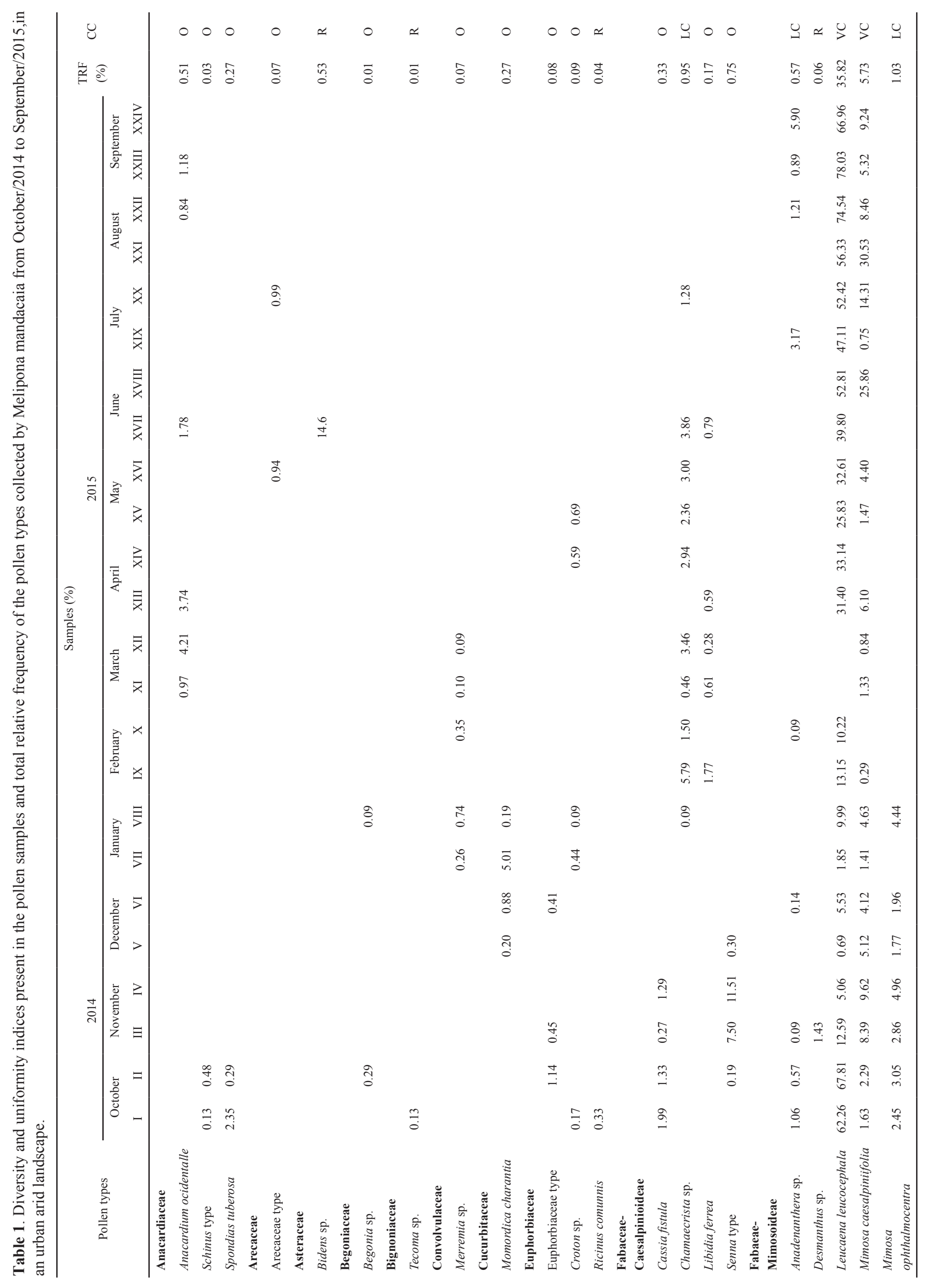




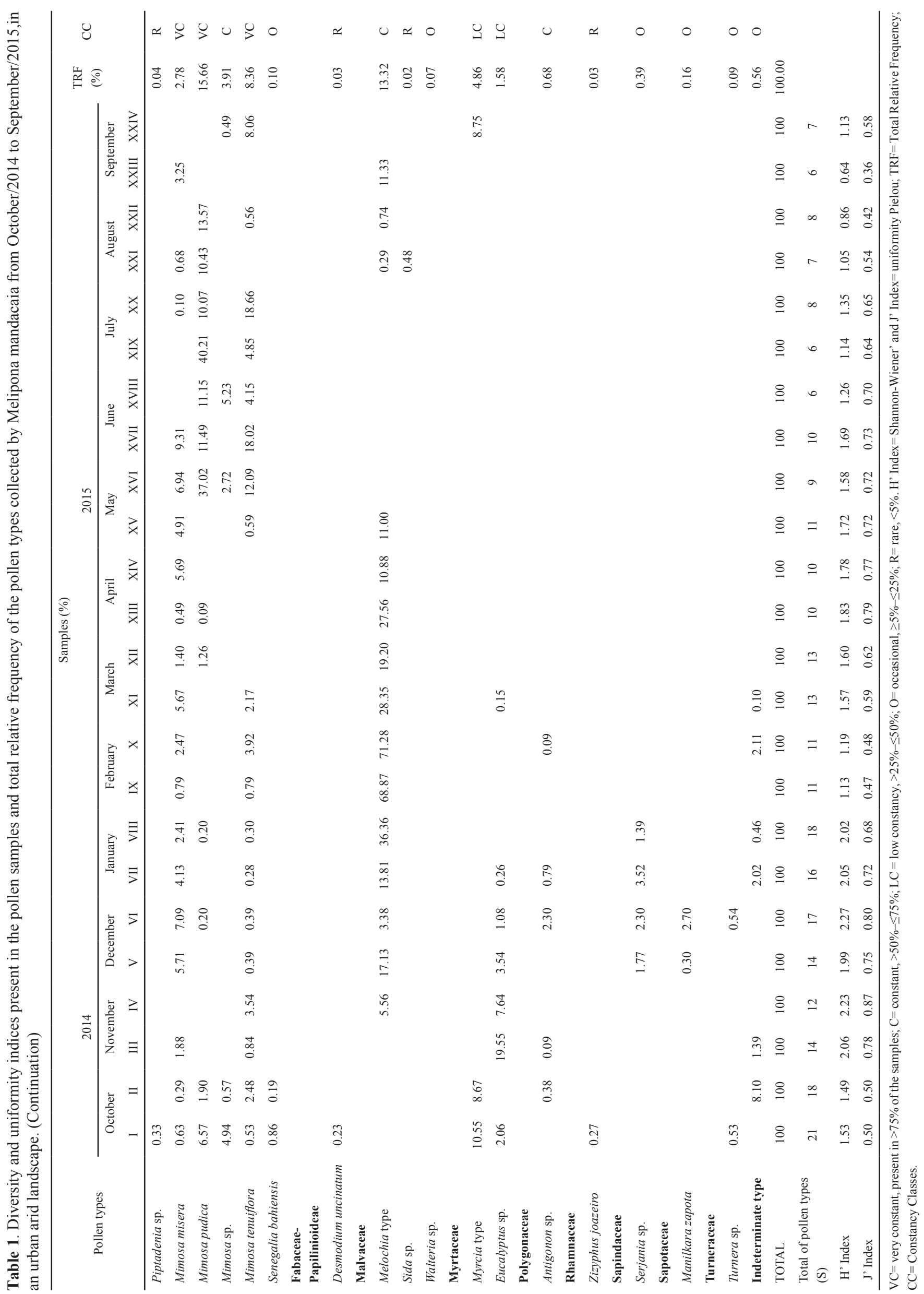




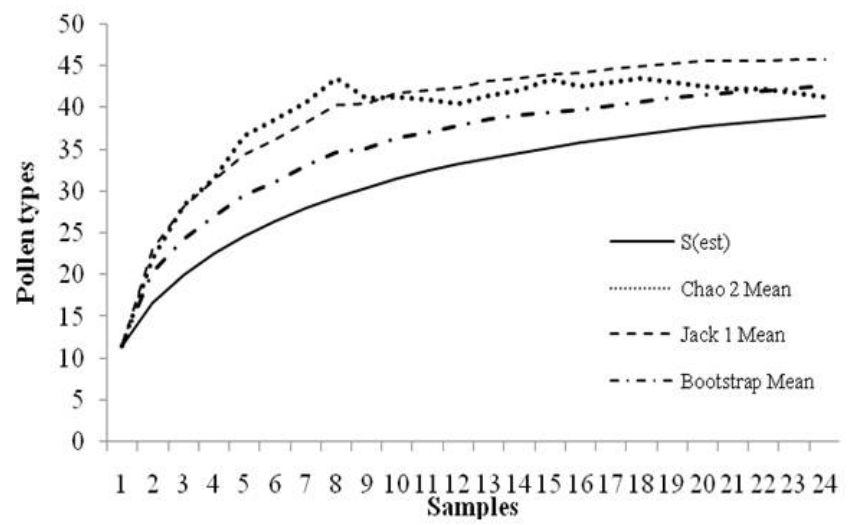

Fig 3. Rarefaction curve and richness estimators (Chao 2. Jack 1. and bootstrap) of the pollen types collected in pollen pots of Melipona mandacaia nests in an urban arid.

Table 2. Sörensen's similarity coefficient in the composition of the pollen types of the three colonies of M. mandacaia, from October/2014 to September/2015, in an urban arid landscape. $\mathrm{Cs}>0.7$.

\begin{tabular}{lll}
\hline & Colony II & Colony III \\
\hline Colony I & 0.93 & 0.79 \\
Colony II & - & 0.83 \\
\hline
\end{tabular}

\section{Discussion}

In the present study, it was observed that many plants contributed to guarantee the maintenance of colonies of $M$. mandacaia. It is worth mentioning that the study area is a fragment of the riparian forest of the São Francisco River, made up of caatinga species and exotic plants, also composed of irrigated crops, being located in the urban area. Possibly, accidental pollen grains may have contaminated the mass transported during bees' activities in the flowers, contributing to increase the number of pollen types with low representativity (Carvalho et al., 1999). From this assumption, and considering that the total frequencies of pollen types less than $0.5 \%$,as proposed by Eltz et al. (2001) in their study, which should be considered as contaminations, there would remain only 18 pollen types in our study representing the plants visited by the bees for pollen collection. This result shows a high selectivity and floral preference for plants that supply large quantities of pollen (Maia-Silva et al., 2014).

A few species was collected in Ribeirão Preto (SP), 23 plant species of Melipona quadrifasciata, and 18 species of Melipona subnitida (Maia-Silva et al., 2014). Conceição (2013) recorded 17 pollen types when identifying the botanical profile of the stored pollen (samburá) of Melipona quadrifasciata anthidioides, in the semi-arid state of Bahia-Brazil. In native vegetation of the Caatinga in the state of Paraiba, 14 pollen types collected by Melipona subnita were identified (MaiaSilva et al., 2015), whereas 52 pollen types for the same bee in the Lençóis Maranhenses National Park-Brazil (Pinto et al., 2014). The intrinsic learning of each colony, genetic characteristics, flower characteristics, availability of trophic resources and different levels of competition, are factors that influence the bees' collection behavior (Modro et al., 2011; Oliveira et al., 2009).

The pollen type L. leucocephala is a widely cultivated forage, with irrigation for animal feed in the study area, in addition to what occurs in a sub spontaneous way. In a study carried out in a forest fragment in Manaus, northern Brazil, Oliveira et al. (2009) of the eight species of Fabaceae-Mimosoideae identified in the pollen samples, L. leucocephala was the most important, being widely used by Melipona seminigra merrillae and Melipona fulva. According to the authors, L. leucocephala blooms the entire year and its inflorescence in cream-colored flower head provides large amount of pollen, which are collected by bees early in the morning.

In a study conducted in Petrolina-PE, located in the San Francisco Valley, Northeast Brazil, just as with M. mandacaia, the $L$. leucocephala species showed a total frequency between $16-45 \%$ in samples collected in an urban area (Braga et al., 2012), corroborating the results reported here.

Inthe Assu-RN National Forest (biome Caatinga), in studies with the species of stingless bee Melipona subnitida and Plebeia aff flavocincta, this species was also recorded, but with low frequency in the samples (Azevedo-Costa et al., 2013).Several genus and species recorded in their study were also recorded in our study, such as the Chamaecrista sp., Anadenanthera colubrina (Vell.) Brenan, Eucalyptus spp., Mimosa tenuiflora (Willd.) Poir., Senna spp., Croton spp., Anacardium sp. and Turnera melochioides Cambess. Antagonistically to our study, the most constant pollen types were M. tenuiflora, Senna sp., Chamaecrista sp. and M. arenosa.

The Melochia species, flowers throughout the year and offers two floral resources (nectar and pollen) during the rainy season of the Caatinga ecosystem, favoring the maintenance of bee populations and other floral visitors, being a key resource in the Northeastern semi-arid of Brazil (Machado \& Sazima, 2008).

When small flowers are arranged in dense inflorescences, they allow the visiting of medium and large bees. Examples of species with small flowers that are, however, very attractive due to their organization in dense inflorescences are found in many legumes (Fabaceae), such as A. colubrina, M. tenuiflora (Machado \& Lopes, 2004), M. pudica, M. misera and M. caesalpiniifolia. This justifies the bees' preference for the Fabaceae family.

In a floristic survey in Southeastern Brazil, the Fabaceae family with the highest species richness was recorded in the study area (Aleixo et al., 2014), being also observed by Conceição (2013) in the Baiano-Northeastern Brazilian Semi-arid.

A number of studies with native stingless bees highlight the importance of the Fabaceae family as the main supplier of pollen (Aleixo et al., 2013; Azevedo-Costa et al., 2013; MaiaSilva et al., 2014). Studies performed by Alves et al. (2006) to identify M. mandacaia nectar sources in the state of Bahia- 
Brazil, Souza et al. (2015) of M. scutellaris on the north coast of Bahia, Matos and Santos (2016) of M. scutellaris in an Atlantic Forest area in the state of Bahia, and Martins et al. (2011) of Melipona fasciculata in the state of MaranhãoBrazil, indicated that the greatest diversity of types was also for the Fabaceae family. Therefore, this family, besides being the main supplier of pollen throughout the year, is one of the main sources of nectar for the stingless bees.

In the southeast of Brazil, in Ribeirão Preto (SP), the period with the highest number of plants supplying pollen was observed during the rainy season with positive correlation (Aleixo et al., 2014). The highest number of pollen types collected by bees in our study also occurred in the period considered as rainy (October to April) in the Region of the SubmediumValley of San Francisco.

The period with the highest number of worker bees collecting pollen for Frieseomelitta varia, another species of stingless bee, was recorded in October (Aleixo et al., 2013) and the pollen activity was not influenced by the climatic factors. In the present study, it was recorded that the greatest diversity of pollen types was found in October and influenced by temperature.

The rarefaction curve showed that probably most of the pollen types collected by the studied bees were sampled, since the accumulation curve presented a progressive tendency to stabilization, indicating that there was sufficient sample of the pollen types.

The fact that the accumulation curve did not stabilize indicates that there may still be pollen types that were not recorded in the study area, suggesting that the diversity of pollen types in the study area is larger than that observed. Based on the values obtained by the richness estimators, one may suggest that between $85 \%$ and $93 \%$ of the pollen types collected by bees population of $M$. mandacaia the study site has been effectively sampled, although the curves of these estimators have been completely stabilized.Through pollen analysis, it was observed that the studied colonies share several pollen types.

\section{Acknowledgments}

The authors are grateful to Dra. Gertrudes Macario de Oliveira for all the meteorological data, Dra. Lúcia H. P. Kiill and Tatiana Ayako Taura for the support in the making of the map, the anonymous reviewer for helpful comments on an earlier version of the manuscript and the State University of Bahia for providing the necessary infrastructure for this experiment.

\section{References}

Aleixo, K.P., Faria, L.B., Groppo, M., Castro, M.M.N. \& Silva, C.I. (2014). Spatiotemporal distribution of floral resources in a Brazilian city: Implications for the maintenance of pollinators, especially bees. Urban Forestry and Urban Greening, 13: 689-696. doi: 10.1016/j.ufug.2014.08.002

Aleixo, K.P., Faria, L.B., Garófalo, C.A., Imperatriz-Fonseca, V.L. \& Silva, C.I. (2013). Pollen Collected and Foraging Activities of Frieseomelitta varia (Lepeletier) (Hymenoptera: Apidae) in an Urban Landscape. Sociobiology, 60: 266-276. doi: 10.13102/sociobiology.v60i3.266-276

Alves, R.M.O., Carvalho, C.A.L. \& Souza, B.A. (2006). Espectro polínico de amostras de mel de Melipona mandacaia Smith, 1863 (Hymenoptera: Apidae). Acta Scientarum - Biological Sciences, 28: 65-70.doi: 10.4025/actascibiolsci.v28i1.1061

Azevedo-Costa, C.C.A., Silva, C.I., Imperatriz-Fonseca, V.L \& Oliveira, F.L. (2013). Origem floral dos recursos coletados por Melipona subnitida e Plebeia aff flavocincta (Apinae, Meliponini) em ambiente de caatinga. Caderno Verde de Agroecologia e Desenvolvimento Sustentável, 3: 90-95.

Batalha-Filho, H., Waldschmidt, A.M., \& Alves, R.M.O. (2011). Distribuição potencial da abelha sem ferrão endêmica da Caatinga, Melipona mandacaia (Hymenoptera, Apidae). Magistra, 23: 129-133.

Braga, J.R., Lima, C.B.S., Rodrigues, F., Santos, H.C. \& Ribeiro, M.F. (2012). Tipos polínicos coletados por Melipona mandacaia (Hymenoptera, Apidae, Meliponini) em PetrolinaPE. Documentos (Embrapa Semi-Árido. Online), 248: 35-41.

Carvalho, C.A.L., Marchini, L.C. \& Ros, P.B. (1999). Fontes de pólen utilizadas por Apis mellifera L. e algumas espécies de Trigonini (Apidae) em Piracicaba (SP). Bragantia, 58: 4956. doi: 10.1590/S0006-87051999000100007

Colwell, R.K. (2013). Estimates: Statistical estimation of species richness and shared species from samples. Version 9. User's Guide and application available online at http://purl. oclc.org/estimates.

Colwell, R.K. \& Coddington J.A. (1994) Estimating terrestrial biodiversity thourgh extrapolation. Philosophical Transactions of the Royal Society of London, B, 345: 101118. doi: $10.1098 /$ rstb.1994.0091

Conceição, P.J. (2013). Levantamento florístico e perfil botânico do pólen (samburá) da abelha Melipona quadrifasciata anthidioides Lepeletier, 1836 (Hymenoptera: Apidae) da Região Semiárida, Estado da Bahia. Dissertação (Mestrado em Ciências Agrárias)-Centro de Ciências Agrárias, Ambientais e Biológicas Cruz das Almas: Universidade Federal do Recôncavo, 2013.

Eltz, T., Brühl1, C.A., van der Kaars, S., Chey, V. K. \& Linsenmair, K. E. (2001). Pollen foraging and resource partitioning of stingless bees in relation to flowering dynamics in a southeast Asian tropical rainforest. Insectes Sociaux, 48: 273-279. doi: 10.1007/PL00001777

EMBRAPA. Dados Meteorológicos, Estação Agrometeorológica de Mandacarú, Juazeiro-BA. Disponível em $<$ www. cpatsa.embrapa.br>. Acesso em 04.07.2015. 
Hammer, O., Harper, D.A.T. \& Ryan, P.D. (2001). PAST: Paleontological Statistics software package for education and analysis. Paleontologia Electronica, 4: 9.

Imperatriz-Fonseca, V.L., Canhos, D.A.L., Alves, D.A. \& Saraiva, A.M. (2012). Polinizadores no Brasil - Contribuição e Perspectivas para a Biodiversidade, Uso Sustentável, Conservação e Serviços Ambientais. São Paulo: EDUSP.

Ludwig, J.A. \& Reynolds, J.F. (1988). Statistical ecology. New York: John Wiley. 337p.

Luz, C.F.P., Fernandes-Salomão, T.M., Lage, L.G.A., Resende, H.C., Tavares, M.G. \& Campos, L.A.O. (2011). Pollen sources for Melipona capixaba Moure \& Camargo: an endangered Brazilian stingless bee. Psyche, 2011,107303: 1-7.doi: 10.11 55/2011/107303

Magurran, A.E. (2011). Medindo a diversidade biológica. Translantion Vianna DM, UFPR Publisher, 261 p.

Machado, I.C. \& Sazima, M. (2008). Pollination and breeding system of Melochia tomentosa L. (Malvaceae), a keystone floral resource in the Brazilian Caatinga. Flora, 203: 484-490. doi: 10.1016/j.flora.2007.09.003

Machado, I.C. \& Lopes, A.V. (2004). Floral traits and pollination systems in the Caatinga, a Brazilian tropical dry forest. Annals of Botany, 94: 365-376. doi: 10.1093/aob/mch152

Maia-Silva, C., Imperatriz-Fonseca, V.L, Silva, C.I. \& Hrncir, M. (2014). Environmental windows for foraging activity in stingless bees, Melipona subnitida Ducke and Melipona quadrifasciata Lepeletier (Hymenoptera: Apidae: Meliponini). Sociobiology, 61(4): 378-385. doi: 10.13102/ sociobiology.v61i4.378-385

Maia-Silva, C., Hrncir, M., Silva, C.I. \& Imperatriz-Fonseca, V.L. (2015). Survival strategies of stingless bees (Melipona subnitida) in an unpredictable environment, the Brazilian tropical dry forest. Apidologie, 46: 631-643. doi: 10.1007/ s13592-015-0354-1

Martins, A.C.L., Rêgo. M.C., Carreira, L.M.M. \& Albuquerque, P.M.C. (2011). Espectro polínico de mel de tiúba (Melipona fasciculata Smith, 1854, Hymenoptera, Apidae). Acta Amazonica, 41: 183-190. doi: 10.1590/S0044-59672011 000200001

Matos, V.R. \& Santos, F.A.R. (2016). Pollen in honey of Melipona scutellaris L. (Hymenoptera: Apidae) in an Atlantic Rainforest area in the state of Bahia, Brazil. Palynology, 40 : 1-13. doi: 10.1080/01916122.2015.1115434

Maurizio, A. \& Louveaux, J. (1965). Pollens des plantes mellifères d'Europe. U.G.A.F., Paris, 148p.

Modro, A.F.H., Message, D., Luz, C.F.P. \& Meira-Neto, J.A.A. (2011). Flora de importância polínifera para Apis mellifera L. na região de Viçosa, MG. Revista Árvore, 35: 1145-1153. doi: 10.1590/S0100-67622011000600020
Novais, J.S., Lima, L.C.L.\& Santos, F.A.R. (2009). Botanical affinity of pollen harvested by Apis mellifera L. in a semiarid area from Bahia, Brazil. Grana, 48, 224-234. doi: 10.1080/00173130903037725

Nunes, L.A. (2008). Estudo Morfológico das Populações de Melipona quadrifasciata anthidioides Lepeletier (Hymenoptera: Apidae) na Região Semi-Árida do Estado da Bahia. Dissertação de Mestrado. Universidade Federal do Recôncavo da Bahia. Cruz das Almas, BA, Brasil, 76p.

Oliveira, F.P.M., Absy, M.L. \& Miranda, I.S. (2009). Recurso polínico coletado por abelhas sem ferrão (Apidae, Meliponinae) em um fragmento de floresta na região de Manaus - Amazonas. Acta Amazonica, 39: 505-518. doi: 10.1590/S0044-59672009000300004

Pinto, R.S., Albuquerque, P.M.C. \& Rêgo, M.M.C. (2014). Pollen Analysis of Food Pots Stored by Melipona subnitida Ducke (Hymenoptera: Apidae) in a Restinga area. Sociobiology, 61: 461-469. doi: 10.13102/sociobiology.v61i4.461-469

Prado-Silva, A., Nunes, L.A., Oliveira-Alves, R.M., Carneiro, P.L.S., Waldschmidt, A.M. (2016). Variation of fore wing shape in Melipona mandacaia Smith, 1863 (Hymenoptera, Meliponini) along its geographic range. Journal of Hymenoptera Research, 48: 85-94. doi: 10.3897/ JHR.48.6619

Ramírez-Arriaga, E., Navarro-Calvo, L.A. \& Díaz-Carbajal, E. (2011). Botanical characterization of Mexican honeys from a subtropical region (Oaxaca) based on pollen analysis. Grana 50: 40-54. doi: 10.1080/00173134.2010.537767

Siqueira, K.M.M., Martins, C.F., Kiill, L.H.P. \& Silva, L.T. (2011). Estudo comparativo da polinização em variedades de aceroleiras (Malpighia emarginata DC, Malpighiaceae). Revista Caatinga (UFERSA), 24: 18-25.

Sørensen, T. (1948). A method of establishing groups of equal amplitude in plant sociology based on similarity of species and its application to analyses of the vegetation on Danish commons. Biologiske Skrifter, 5: 1-34.

Souza, L.S., Lucas, C.I.S., Conceição, P.J., Paixão, J.F. \& Alves, R.M.O. (2015). Pollen spectrum of the honey of uruçu bee (Melipona scutellaris Latreille, 1811) (Hymenoptera: Apidae) in the North Coast of Bahia State. Acta ScientiarumBiological Sciences, 37: 483-489. doi: 10.4025/actascibiolsci. v37i4.28059

Steffan-Dewenter, I, Klein, A.M., Gaebele, V., Alfert, T. \& Tscharntke, T. (2006). Bee Diversity and Plant-Pollinator Interactions in Fragmented Landscapes. In: Wasser, N.M. \& Ollerton, J. Plant-Pollinator interactions from specialization to generalization. The University of Chicago Press: E.U.A, p. 387-407.

Wiese, H. (1985). Novo Manual de Apicultura. Porto Alegre: Agropecuária.493 p. 